\title{
PERBEDAAN STATUS GIZI DAN KUALITAS ASUPAN MAKANAN PADA LANSIA YANG MENGIKUTI DAN TIDAK MENGIKUTI PROLANIS
}

\author{
Rosiana Dwi Astiti, Ani Margawati*, Ayu Rahadiyanti, A Fahmy Arif Tsani \\ Departemen Ilmu Gizi, Fakultas Kedokteran, Universitas Diponegoro \\ Jl. Prof. Sudarto SH, Tembalang, Semarang, Jawa Tengah 50275, Indonesia \\ "Penulis Penanggungjawab. E-mail: animargawati@gmail.com
}

\begin{abstract}
Background: The numbers of elderly people are getting increase. The factors that determinated of increasing the number of elderly people such as improving health facilities which caused improving health status, diet quality, and also the government health program such as Prolanis (Program Pengelolaan Penyakit Kronis) or Management Programme of Chronical Diseases. The aim of this study was to analyze the difference of nutritional status and diet quality of elderly who participate and not participate of prolanis programme.

Methods: The design study was cross sectional. Subject was the elderly people who participate prolanis and who were not. Subject was selected by consecutive sampling. Variable including subject identity, income level, nutritional status based on Body Mass Index (BMI), diet quality that was obtained by Diet Quality Index-International (DQI-I) form, and physical activity that was obtained by International Physical Activity Questionnaire (IPAQ) form. Data was analysis by independent t-test and Mann Whitney test.

Findings: The mean of diet quality score was $48.5 \pm 6.7$ which classified as poor-quality diet. The mean of nutritional status was $24.5 \pm 4.2 \mathrm{~kg} / \mathrm{m}^{2}$. The diet quality score of subjects who participate of prolanis (49.0 \pm 7.5$)$ was higher than

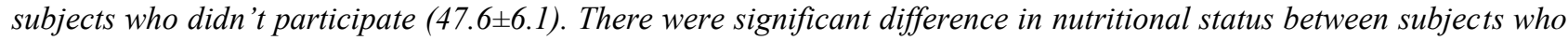
did and did not participate of prolanis programme $(p=0.029)$, but there were no significant difference in diet quality $(p=0.538)$.

Conclusion: There were significant difference in nutritional status based on participation of prolanis programme $(p=0.029)$. There were no significant difference in diet quality based on participation of prolanis programme $(p=0.538)$.
\end{abstract}

Key words: diet quality; nutritional status; elderly; prolanis

\begin{abstract}
ABSTRAK
Latar Belakang: Populasi lansia terus mengalami peningkatan. Peningkatan ini harus diikuti dengan perbaikan fasilitas kesehatan sehingga derajat kesehatan dan kualitas asupan makanan lansia meningkat. Salah satu strategi yang dilaksanakan pemerintah yaitu Program Pengelolaan Penyakit Kronis (Prolanis). Penelitian ini bertujuan untuk mengetahui perbedaan status gizi dan kualitas asupan makanan pada lansia yang mengikuti dan tidak mengikuti prolanis.

Metode: Penelitian ini merupakan studi cross sectional. Subjek merupakan lansia yang mengikuti dan tidak mengikuti prolanis. Data meliputi karakteristik subjek, tingkat pendapatan, status gizi berdasarkan Indeks Massa Tubuh (IMT), kualitas asupan makanan menggunakan formulir Diet Quality Index-International (DQI-I), dan aktivitas fisik dengan metode International Physical Activity Questionnaire (IPAQ). Analisis data menggunakan uji independent t-test dan Mann-Whitney.

Hasil: Rerata skor kualitas asupan makanan subjek yaitu 48,5 $\pm 6,7$ yang tergolong rendah. Rerata status gizi subjek yaitu $24,5 \pm 4,2 \mathrm{~kg} / \mathrm{m}^{2}$. Kualitas asupan makanan subjek yang mengikuti prolanis $(49,0 \pm 7,5)$ lebih tinggi dibandingkan subjek yang tidak mengikuti prolanis $(47,6 \pm 6,1)$. Hasil uji beda menunjukkan terdapat perbedaan pada status gizi antara subjek yang mengikuti dan tidak mengikuti prolanis $(p=0,029)$, tetapi tidak terdapat perbedaan pada kualitas asupan makanan ( $p=0,538)$.

Simpulan: Ada perbedaan signifikan status gizi berdasarkan keikutsertaan prolanis ( $p=0,029)$. Tidak ada perbedaan signifikan kualitas asupan makanan berdasarkan keikutsertaan prolanis $(p=0,538)$.
\end{abstract}

Kata Kunci: kualitas asupan makanan; status gizi; lansia; prolanis

\section{PENDAHULUAN}

Menurut UU RI No 13 tahun 1998 tentang Kesejahteraan Lanjut Usia, lanjut usia (lansia) adalah seseorang yang telah mencapai usia 60 tahun ke atas. ${ }^{1}$ Secara biologis, lansia mengalami proses penuaan secara terus-menerus yang ditandai dengan penurunan daya tahan tubuh karena terjadi penurunan kemampuan jaringan untuk mempertahankan struktur dan fungsinya. Berbagai usaha dilakukan pemerintah dalam program 
pembangunan kesehatan yang diiringi perkembangan teknologi mampu meningkatkan usia harapan hidup (UHH) penduduk Indonesia. Namun di sisi lain terjadinya peningkatan $\mathrm{UHH}$ menimbulkan anggapan bahwa golongan tua merupakan beban. ${ }^{2}$

Usia harapan hidup (UHH) negara Indonesia mengalami peningkatan yaitu tahun 1995-2000 dari 66,0 tahun menjadi 70,1 tahun pada periode tahun 2010-2015. ${ }^{3}$ Hal ini menunjukkan bahwa populasi lansia akan terus meningkat pada tahun selanjutnya. Tiga provinsi di Indonesia dengan jumlah penduduk lansia terbesar yaitu DI Yogyakarta (13,05\%), Jawa Tengah $(11,11 \%)$, dan Jawa Timur $(10,96 \%) .{ }^{4} \mathrm{UHH}$ di Provinsi Jawa Tengah semakin meningkat dari tahun ke tahun. Pada tahun 2010 UHH sebesar 72,73 tahun dan terus meningkat menjadi 74,02 tahun pada tahun 2016. ${ }^{5}$ Kabupaten Wonogiri merupakan kabupaten dengan proporsi penduduk lansia terbesar di Jawa Tengah yaitu $20,24 \% .^{6}$

Selain usia harapan hidup, derajat kesehatan seseorang dapat dinilai berdasarkan status gizi. Status gizi sangat penting untuk mencegah atau mempertahankan tubuh dari berbagai penyakit kronis dan akut, serta berperan dalam proses penyembuhan. Seiring bertambahnya usia, berbagai perubahan terjadi dalam tubuh yang dapat mempengaruhi status gizi seseorang. Malnutrisi pada lansia umumnya berupa gizi lebih dan gizi kurang. Malnutrisi pada lansia dapat menyebabkan berbagai masalah kesehatan diantaranya penurunan sistem kekebalan tubuh, peningkatan risiko infeksi, penyembuhan luka yang lebih lama, kelemahan otot yang dapat menyebabkan jatuh dan patah tulang, serta penurunan nafsu makan. ${ }^{7}$ Gizi lebih pada lansia juga dapat memicu terjadinya penyakit degeneratif seperti penyakit jantung koroner, hipertensi, dan diabetes mellitus. Gizi kurang pada lansia berhubungan dengan penurunan kemampuan fungsional dan peningkatan mortalitas. ${ }^{2}$ Berbagai penelitian membuktikan bahwa prevalensi lansia yang mengalami malnutrisi masih tinggi. Penelitian di Bangladesh menunjukkan lansia yang mengalami gizi kurang $24 \%$, gizi lebih $32 \%$, dan obesitas $12 \%$. Penelitian di Yogyakarta menyebutkan 35,5\% lansia memiliki status gizi lebih dan 18,2\% lansia mengalami gizi kurang. ${ }^{9}$

Kualitas diet atau asupan makanan merupakan salah satu faktor yang mempengaruhi status gizi seseorang. Kualitas asupan makanan menunjukkan kesesuaian asupan makan seseorang berdasarkan rekomendasi yaitu adanya variasi kelompok makanan, kecukupan zat gizi sesuai kebutuhan, moderasi, dan keseimbangan keseluruhan. Penelitian yang dilakukan di China menunjukkan bahwa 80,8\% lansia memiliki ketidakseimbangan konsumsi makanan sedang hingga berat. ${ }^{10}$ Penelitian di Padang menunjukkan bahwa lansia yang memiliki asupan kurang sebesar 51,4\%. ${ }^{11}$ Kualitas asupan makanan yang baik pada lansia sangat diperlukan untuk mengontrol dan mencegah komplikasi penyakit degeneratif serta dapat membantu memperbaiki status gizinya. ${ }^{7}$

Lansia membutuhkan pelayanan kesehatan khusus untuk mengetahui kondisi kesehatannya. Salah satu bentuk strategi yang dilaksanakan pemerintah melalui Badan Penyelenggara Jaminan Sosial (BPJS) Kesehatan yaitu Program Pengelolaan Penyakit Kronis (Prolanis) khususnya untuk pasien hipertensi dan diabetes mellitus. Kegiatan prolanis terkait pendidikan dan promosi kesehatan berperan penting dalam menjaga kesehatan, mobilitas, dan status fungsional pada lansia. Namun, tidak semua lansia memanfaatkan pelayanan kesehatan secara optimal karena berbagai faktor diantaranya kurangnya pengetahuan dan kesadaran akan pentingnya pemanfaatan pelayanan kesehatan, kurangnya dukungan dan motivasi keluarga, kesibukan pekerjaan ataupun menjaga cucucucunya, serta tidak memiliki jaminan kesehatan. ${ }^{12,13}$

Berdasarkan data Badan Pusat Statistik (BPS), sebanyak $58,19 \%$ masyarakat Wonogiri belum memiliki jaminan kesehatan sehingga tidak semua lansia dapat menjadi peserta prolanis. ${ }^{14}$ Selain itu, belum banyak penelitian mengenai kualitas asupan makanan pada lansia di Indonesia, padahal kualitas asupan makanan erat kaitannya dengan status gizi lansia. Berdasarkan pemaparan permasalahan tersebut, peneliti tertarik untuk meneliti perbedaan status gizi dan kualitas asupan makanan pada lansia yang mengikuti dan tidak mengikuti prolanis.

\section{METODE}

Penelitian ini merupakan penelitian analitik observasional dengan desain cross sectional yang dilakukan di wilayah kerja Puskesmas Wonogiri 1 Kabupaten Wonogiri. Penelitian ini termasuk dalam lingkup gizi masyarakat. Pengambilan data dilakukan pada bulan Maret-April 2019.

Populasi target pada penelitian ini adalah lansia usia 60-70 tahun di Kabupaten Wonogiri. Pemilihan subjek dengan cara consecutive sampling diawali pengumpulan data peserta prolanis dan skrining terhadap lansia yang memenuhi kriteria. Total sampel sebanyak 73 orang yang memenuhi kriteria inklusi dan eksklusi. Penelitian ini telah mendapat surat izin etik No. 79/EC/FK UNDIP/III/2019.

Kriteria inklusi pada penelitian ini yaitu kooperatif dan komunikatif, tidak menderita penyakit infeksi, tidak mengalami demensia, dan masih dapat melakukan aktivitas fisik dengan 
normal. Kriteria eksklusi dalam penelitian ini adalah meninggalkan lokasi penelitian, mengalami disabilitas, tidak dapat berdiri tegak, tidak memiliki gigi atau memiliki gangguan makan, dan mengalami gangguan jiwa.

Data yang dikumpulkan dalam penelitian ini adalah karakteristik subjek, tingkat pendapatan, data antropometri, kualitas asupan makanan, dan aktivitas fisik. Variabel bebas dalam penelitian ini yaitu keikutsertaan prolanis yang dibagi menjadi 2 kelompok yaitu subjek yang mengikuti dan tidak mengikuti prolanis. Subjek yang dikatakan mengikuti prolanis dalam penelitian ini adalah peserta prolanis yang melaksanakan semua program prolanis (pemeriksaan kesehatan, promosi kesehatan, senam) minimal 3 bulan terakhir secara berurutan.

Variabel terikat dalam penelitian ini yaitu status gizi dan kualitas asupan makanan. Status gizi lansia diukur menggunakan Indeks Massa Tubuh (IMT) berdasarkan berat badan dan tinggi badan. Pengukuran berat badan dan tinggi badan dilakukan sebanyak 2 kali. Penimbangan berat badan menggunakan timbangan injak digital dengan ketelitian $0,1 \mathrm{~kg}$ dan tinggi badan diukur menggunakan mikrotoa dengan ketelitian $0,1 \mathrm{~cm}$ yang ditempelkan di dinding.
Kualitas asupan makanan merupakan penilaian asupan makanan yang dilihat dari 4 komponen utama yaitu variasi, kecukupan, moderasi, dan keseimbangan keseluruhan berdasarkan Pedoman Umum Gizi Seimbang (PUGS) dan Angka Kecukupan Gizi (AKG). Pengambilan data asupan dilakukan melalui wawancara menggunakan formulir recall 3x24 jam secara tidak berurutan. Analisis asupan zat gizi menggunakan software Nutrisurvey 2007. Kebutuhan energi dihitung menggunakan rumus Harris-Benedict, sedangkan kebutuhan zat gizi mikro berdasarkan AKG yang disesuaikan dengan berat badan subjek. Data kualitas asupan makanan didapatkan dari rerata data asupan makanan yang diinterpretasi menggunakan instrumen Diet Quality Index-International (DQI-I). Total nilai dalam DQI-I yaitu $0-100$

Tingkat pendapatan dan aktivitas fisik menjadi variabel perancu dalam penelitian ini. Pengambilan data aktivitas fisik menggunakan formulir International Physical Activity Questionnaire (IPAQ) untuk mengetahui aktivitas fisik subjek tergolong rendah $(<3000$ MET/min/minggu $)$ atau tinggi $(\geq 3000$ $\mathrm{MET} / \mathrm{min} / \mathrm{minggu}$ ). Analisis data menggunakan uji independent t-test dan Mann-Whitney.

Tabel 1. Karakteristik Subjek Penelitian

\begin{tabular}{|c|c|c|c|c|c|}
\hline Variabel & $\mathbf{n}$ & $\%$ & Rerata \pm SD & Min & Max \\
\hline \multicolumn{6}{|l|}{ Jenis kelamin } \\
\hline Laki-laki & 31 & 42,5 & & & \\
\hline Perempuan & 42 & 57,5 & & & \\
\hline Usia (tahun) & & & $65,05 \pm 3,4$ & 60 & 70 \\
\hline $60-64$ & 29 & 39,7 & & & \\
\hline $65-70$ & 44 & 60,3 & & & \\
\hline Status gizi $\left(\mathrm{kg} / \mathrm{m}^{2}\right)^{15}$ & & & $24,5 \pm 4,2$ & 17,4 & 38,3 \\
\hline Gizi kurang $<18,5$ & 3 & 4,1 & & & \\
\hline Normal $18,5-25,0$ & 43 & 58,9 & & & \\
\hline Gizi lebih $>25,0$ & 27 & 37,0 & & & \\
\hline \multicolumn{6}{|c|}{ Aktivitas fisik (METs/min/minggu) ${ }^{16,17}$} \\
\hline Rendah $(<3000)$ & 43 & 58,9 & & & \\
\hline Tinggi $(\geq 3000)$ & 30 & 41,1 & & & \\
\hline \multicolumn{6}{|l|}{ Pendidikan ${ }^{18}$} \\
\hline Dasar & 45 & 61,6 & & & \\
\hline Menengah & 14 & 19,2 & & & \\
\hline Tinggi & 14 & 19,2 & & & \\
\hline \multicolumn{6}{|l|}{ Tingkat pendapatan ${ }^{19}$} \\
\hline$<\mathrm{UMK}$ & 32 & 43,8 & & & \\
\hline$>\mathrm{UMK}$ & 41 & 56,2 & & & \\
\hline
\end{tabular}

\section{HASIL}

Subjek merupakan lansia usia 60-70 tahun di wilayah kerja Puskesmas Wonogiri 1 yang mengikuti Prolanis dan tidak mengikuti Prolanis. Tabel 1 menunjukkan sebagian besar subjek adalah perempuan $(57,5 \%)$. Rata-rata usia subjek sebesar
$65,05 \pm 3,4$ tahun. Sebagian besar subjek memiliki status gizi normal $(58,9 \%)$. Subjek dengan malnutrisi lebih banyak yang tergolong status gizi lebih dibanding status gizi kurang. Sebagian besar subjek $(58,9 \%)$ memiliki aktivitas fisik yang tergolong rendah. Mayoritas tingkat pendidikan 
subjek adalah pendidikan dasar (SD dan SMP) (61,6\%). Sebanyak 56,2\% subjek memiliki pendapatan lebih besar dari Upah Minimum Kabupaten (UMK) Kabupaten Wonogiri (Rp1.650.000,00).

\section{Kualitas Asupan Makanan}

Komponen variasi digunakan untuk menilai apakah asupan berasal dari sumber makanan yang beragam baik dari berbagai kelompok makanan maupun kelompok sumber protein. Asupan makanan memiliki skor variasi apabila dikonsumsi setidaknya satu porsi makanan perhari dari masing-masing kelompok makanan dan lebih dari setengah porsi perhari dari masing-masing sumber protein. Variasi asupan lansia pada semua kelompok makanan cukup tinggi namun variasi dalam sumber protein masih rendah. Hasil penelitian menunjukkan skor variasi pada asupan lansia sudah cukup bervariasi dengan rerata $14,0 \pm 2,6$.
Komponen kecukupan digunakan untuk mengevaluasi bahwa asupan zat gizi telah sesuai dengan kebutuhan. Asupan sayuran dan buah subjek masih rendah dengan skor minimal 0 dan maksimal 3. Skor asupan padi-padian dan protein pada lansia tergolong tinggi. Skor kecukupan terendah didapatkan pada asupan kalsium dengan rerata hanya $1,1 \pm 0,4$. Skor kecukupan asupan lansia masih rendah dengan rerata $20,3 \pm 3,9$.

Komponen moderasi digunakan untuk mengevaluasi asupan makanan dan zat gizi yang perlu dibatasi karena apabila dikonsumsi berlebihan dapat meningkatkan risiko penyakit kronis. Hasil penelitian menunjukkan skor moderasi pada lansia masih rendah karena asupan makanan subjek dalam komponen moderasi tergolong berlebih. Sebagian besar subjek dalam penelitian ini memiliki skor 0 pada komponen makanan rendah zat gizi (gula, minyak, alkohol).

Tabel 2. Gambaran Kualitas Asupan Makanan pada Subjek

\begin{tabular}{lcccc}
\hline \multicolumn{1}{c}{ Variabel } & Rerata \pm SD & Min & Max & Range \\
\hline Variasi (Skor) & $14,0 \pm 2,6$ & 7 & 18 & $0-20$ \\
Semua kelompok makanan & $11,5 \pm 2,0$ & 6 & 15 & $0-15$ \\
Sumber protein & $2,5 \pm 1,1$ & 1 & 5 & $0-5$ \\
Kecukupan (Skor) & $20,3 \pm 3,9$ & 6 & 28 & $0-40$ \\
Kelompok sayuran & $1,5 \pm 0,9$ & 0 & 3 & $0-5$ \\
Kelompok buah & $2,1 \pm 1,5$ & 0 & 5 & $0-5$ \\
Kelompok padi-padian & $4,6 \pm 1,0$ & 1 & 5 & $0-5$ \\
Serat & $1,5 \pm 0,9$ & 1 & 3 & $0-5$ \\
Protein & $4,2 \pm 1,1$ & 1 & 5 & $0-5$ \\
Besi & $2,5 \pm 1,0$ & 1 & 5 & $0-5$ \\
Kalsium & $1,1 \pm 0,4$ & 0 & 3 & $0-5$ \\
Vitamin C & $2,9 \pm 1,5$ & 1 & 5 & $0-5$ \\
Moderasi (Skor) & $13,2 \pm 3,1$ & 9 & 27 & $0-30$ \\
Total lemak & $1,5 \pm 1,8$ & 0 & 6 & $0-6$ \\
Lemak jenuh & $0,2 \pm 1,1$ & 0 & 6 & $0-6$ \\
Kolesterol & $5,8 \pm 0,7$ & 3 & 6 & $0-6$ \\
Natrium & $5,4 \pm 1,2$ & 3 & 6 & $0-6$ \\
Makanan rendah zat gizi & $0,2 \pm 0,7$ & 0 & 6 & $0-6$ \\
Keseimbangan keseluruhan (Skor) & $1,0 \pm 2,0$ & 0 & 6 & $0-10$ \\
Rasio makronutrien & $1,0 \pm 2,0$ & 0 & 6 & $0-6$ \\
Rasio asam lemak & 0 & 0 & 0 & $0-4$ \\
Total kualitas asupan makanan (Skor) & $48,5 \pm 6,7$ & 25 & 63 & $0-100$ \\
\hline
\end{tabular}

Komponen keseimbangan keseluruhan dinilai dalam bentuk proporsionalitas pada sumber energi dari zat gizi makro dan asam lemak. Skor rasio zat gizi makro tergolong rendah karena adanya ketidakseimbangan asupan karbohidrat, lemak, dan protein yang dikonsumsi subjek. Skor rasio asam lemak menunjukkan bahwa keseluruhan subjek memiliki asupan Saturated Fatty Acid (SFA) lebih tinggi dibandingkan asupan Polyunsaturated Fatty Acid (PUFA) dan Monounsaturated Fatty Acid (MUFA). Kualitas asupan makanan lansia secara keseluruhan tergolong rendah dengan rata-rata $48,5 \pm 6,7$ poin dengan skor minimal 25 dan skor maksimal 63 .

Tabel 3 menunjukkan bahwa status gizi berdasarkan tingkat pendapatan dan aktivitas fisik tidak menunjukkan perbedaan yang signifikan ( $>00,05)$. Tidak adanya perbedaan yang signifikan juga terjadi pada kualitas asupan makanan berdasarkan tingkat pendapatan dan aktivitas fisik $(\mathrm{p}>0,05)$. 
Tabel 3. Perbedaan Kualitas Asupan Makan dan Status Gizi berdasarkan Tingkat Pendapatan dan Aktivitas Fisik

\begin{tabular}{|c|c|c|c|c|c|c|}
\hline \multirow{3}{*}{ Variabel } & \multicolumn{2}{|c|}{ Tingkat Pendapatan } & \multicolumn{4}{|c|}{ Aktivitas Fisik } \\
\hline & $\begin{array}{l}<\text { UMK } \\
(n=32)\end{array}$ & $\begin{array}{l}>\text { UMK } \\
(n=41)\end{array}$ & \multirow[t]{2}{*}{$\mathbf{p}$} & $\begin{array}{l}\text { Rendah } \\
(\mathrm{n}=43)\end{array}$ & $\begin{array}{c}\text { Tinggi } \\
(\mathbf{n}=\mathbf{3 0})\end{array}$ & \multirow[t]{2}{*}{$\mathbf{p}$} \\
\hline & \multicolumn{2}{|c|}{ Mean \pm SD } & & \multicolumn{2}{|c|}{ Mean \pm SD } & \\
\hline Status gizi & $24,2 \pm 3,9$ & $24,8 \pm 4,5$ & $0,567 * *$ & $24,7 \pm 4,2$ & $24,3 \pm 4,3$ & $0,537 * *$ \\
\hline Kualitas asupan makanan & $47,0 \pm 7,1$ & $50 \pm 6,1$ & $0,737^{*}$ & $48,3 \pm 6,5$ & $48,7 \pm 7,1$ & $0,409 *$ \\
\hline
\end{tabular}

Tabel 4. Perbedaan Kualitas Asupan Makanan dan Status Gizi berdasarkan Keikutsertaan Prolanis

\begin{tabular}{lccc}
\hline \multirow{2}{*}{ Variabel } & \multicolumn{2}{c}{ Keikutsertaan Prolanis } \\
\cline { 2 - 3 } & $\begin{array}{c}\text { Mengikuti } \\
(\mathbf{n = 3 5 )}\end{array}$ & $\begin{array}{c}\text { Tidak Mengikuti } \\
(\mathbf{n}=\mathbf{3 8})\end{array}$ & $\mathbf{p}$ \\
\cline { 2 - 3 } & Mean \pm SD & Mean \pm SD & $0,029^{* *}$ \\
Status gizi & $25,5 \pm 3,9$ & $23,7 \pm 4,4$ & $0,538^{*}$ \\
Kualitas asupan makanan & $49,0 \pm 7,5$ & $47,8 \pm 6,1$ & $0,451^{* *}$ \\
Variasi & $14,1 \pm 2,6$ & $13,8 \pm 2,6$ & $0,559^{* *}$ \\
Kecukupan & $20,4 \pm 4,2$ & $20,3 \pm 3,8$ & $0,746^{* *}$ \\
Moderasi & $13,4 \pm 3,5$ & $12,8 \pm 2,9$ & $0,800^{* *}$ \\
Keseimbangan keseluruhan & $1,1 \pm 2,0$ & $0,9 \pm 1,9$ & \\
\hline *jim
\end{tabular}

*uji independent t-test; ** uji mann whitney

Tabel 4 menunjukkan adanya perbedaan yang signifikan pada variabel status gizi kedua kelompok $(\mathrm{p}=0,029)$. Selain itu, diketahui kualitas asupan makanan pada lansia yang mengikuti prolanis lebih baik. Kualitas asupan makanan pada kelompok yang mengikuti prolanis lebih tinggi $(49,0 \pm 7,5)$ dibandingkan kelompok yang tidak mengikuti prolanis $(47,6 \pm 6,1)$. Lansia yang mengikuti prolanis juga memiliki skor yang lebih tinggi pada setiap komponen kualitas asupan makanan diantaranya variasi, kecukupan, moderasi, dan keseimbangan keseluruhan. Meskipun lansia yang mengikuti prolanis memiliki skor lebih tinggi namun kualitas asupan makanan pada kedua kelompok masih tergolong rendah karena skor kualitas asupan makanan pada kedua kelompok $\leq 60$. Kualitas asupan makanan lansia yang tergolong baik sebanyak 4 subjek, yaitu 3 subjek yang mengikuti prolanis dan 1 subjek tidak mengikuti prolanis. Berdasarkan perhitungan statistik, diketahui bahwa kualitas asupan makanan dan setiap komponennya (variasi, kecukupan, moderasi dan keseimbangan keseluruhan) tidak menunjukkan perbedaan yang signifikan.

\section{PEMBAHASAN}

Sebagian besar subjek dalam penelitian ini berjenis kelamin perempuan. Hal ini sesuai dengan penelitian sebelumnya yang menunjukkan populasi lansia perempuan lebih tinggi dan usia harapan hidup perempuan lebih tinggi. ${ }^{20-22}$ Berdasarkan pengukuran status gizi, subjek yang mengalami malnutrisi sebesar $41,1 \%$ dengan proporsi lebih banyak lansia yang memiliki status gizi lebih dibandingkan lansia yang memiliki status gizi kurang. Hal ini sejalan dengan penelitian di Semarang Selatan yang menunjukkan lansia dengan status gizi lebih sebanyak 50\%. ${ }^{10,23,24}$ Gizi lebih pada lansia terjadi karena lansia mengalami perubahan komposisi tubuh yang mengakibatkan kehilangan massa otot dan peningkatan lemak tubuh, selain itu lansia juga mengalami penurunan aktivitas fisik yang menyebabkan penumpukan lemak tubuh..$^{25,26}$

Sebagian besar subjek memiliki aktivitas fisik yang rendah. Hal ini dapat terjadi karena subjek sudah tidak bekerja lagi dan kegiatan yang dilakukan merupakan aktivitas fisik yang ringan seperti mengerjakan pekerjaan rumah. Jenis aktivitas fisik yang banyak dilakukan oleh lansia adalah berjalan kaki dan senam. Lansia yang mengikuti Prolanis secara rutin melakukan senam satu kali setiap bulan. Hal ini sejalan dengan penelitian di Bali yang menunjukkan bahwa sebagian besar lansia memiliki aktivitas fisik ringan sebanyak $56,9 \% .{ }^{27}$ Berdasarkan aspek sosial ekonomi, diketahui bahwa mayoritas subjek memiliki tingkat pendidikan dasar dan pendapatan lebih dari UMK.

Kualitas asupan makanan terdiri dari empat komponen utama yaitu variasi, kecukupan, moderasi, dan keseimbangan keseluruhan. Hasil analisis menunjukkan skor variasi sudah cukup baik dengan rerata sebesar $14,0 \pm 2,6$. Skor variasi lansia tidak maksimal didapatkan dari rendahnya variasi konsumsi protein dalam satu hari. Lansia lebih banyak mengonsumsi sumber protein dari satu atau dua jenis makanan saja. Hal ini berkaitan dengan 
pola konsumsi sebagian besar masyarakat Indonesia yang masih menganggap daging sapi merupakan barang mewah dan biasa dikonsumsi hanya pada acara-acara tertentu. ${ }^{28,29}$ Dalam penelitian ini, sumber protein yang paling banyak dikonsumsi berasal dari kacang-kacangan, hal ini disebabkan bahan makanan ini sangat mudah didapatkan di sekitar tempat tinggal subjek dengan harga yang terjangkau.

Skor komponen kecukupan lansia masih rendah dengan rerata 20,3 $\pm 3,9$. Rata-rata lansia mengonsumsi sayuran dan buah setiap hari namun jumlah yang dikonsumsi tidak memenuhi jumlah yang dianjurkan. Hal ini sejalan dengan penelitian di India yang menunjukkan asupan sayuran berdaun pada lansia hanya mencukupi $42,5 \%$ dari yang dianjurkan. ${ }^{30}$ Kecukupan kelompok padi-padian pada lansia tergolong tinggi karena asupan sudah memenuhi jumlah yang dianjurkan. Hal ini sesuai dengan penelitian di China yang menunjukkan asupan kelompok padi-padian memenuhi jumlah yang dianjurkan. ${ }^{31}$ Sebagian besar lansia cenderung menyukai ubi, gembili, dan singkong yang diolah dengan cara direbus untuk makanan selingan . Kecukupan serat dan vitamin $\mathrm{C}$ lansia yang rendah berkaitan dengan rendahnya konsumsi buah dan sayur. Hal ini sejalan dengan penelitian sebelumnya yang menunjukkan asupan serat sebagian besar lansia tergolong rendah dengan rerata sekitar 8-9,4 gram/hari. ${ }^{23,32}$ Kecukupan protein subjek tergolong baik karena subjek cenderung menyukai olahan kacang-kacangan baik untuk sayur, lauk, maupun selingan. Hal ini sejalan dengan penelitian sebelumnya yang menunjukkan sebagian besar lansia memenuhi kebutuhan asupan protein dengan kecukupan sekitar 10,37-11\% dari kebutuhan., ${ }^{9,33}$ Kecukupan asupan kalsium lansia dalam penelitian ini tergolong rendah. Hal ini sejalan dengan penelitian Kim yang menunjukkan asupan kalsium lansia hanya memenuhi $43 \%$ kebutuhan $(335,6 \pm 191,4 \mathrm{mg}) \cdot{ }^{34-36}$ Sumber kalsium yang banyak dikonsumsi subjek berasal dari sumber nabati diantaranya bayam, kenikir, daun singkong, tempe, dan tahu.

Skor komponen moderasi lansia tergolong rendah karena konsumsi lemak dan makanan yang rendah zat gizi lebih tinggi dari yang dianjurkan. Hal ini sejalan dengan penelitian lansia di Semarang yang menunjukkan bahwa asupan lemak pada lansia cukup tinggi jika dibandingkan asupan hariannya. ${ }^{37}$ Pada penelitian ini, asupan lemak yang tinggi disebabkan lansia cenderung menyukai lauk yang digoreng karena dianggap sebagai cara pengolahan makanan paling mudah dan juga olahan santan karena dinilai bisa membangkitkan selera makan. Selain itu, lansia cenderung menyukai olahan gorengan yang digunakan untuk makanan selingan, seperti pisang goreng, sukun goreng, bakwan, dan mendoan. Skor tertinggi pada komponen konsumsi lemak dan makanan rendah zat gizi terjadi pada lansia yang cenderung memilih lauk yang diolah dengan cara direbus atau dipanggang serta tidak menyukai konsumsi minuman manis. Skor komponen kolesterol dan natrium subjek tergolong tinggi. Hal ini sejalan dengan penelitian di Banjarmasin yang menunjukkan sebagian besar lansia memiliki asupan kolesterol dan natrium yang baik. ${ }^{38-41}$ Berdasarkan penelitian yang dilakukan, sumber natrium yang diasup lansia sebagian besar berasal dari kecap, ikan asin, dan garam dapur.

Skor komponen keseimbangan keseluruhan tergolong rendah. Skor ini didapatkan dari proporsi asupan makronutrien dan asam lemak yang tidak sesuai dengan kebutuhan. Hal ini sejalan dengan penelitian di China yang menunjukkan skor keseimbangan keseluruhan hanya $0,7 \pm 1,3 .^{40}$ Skor rasio makronutrien rendah didapatkan dari rasio asupan lemak yang cenderung berlebih dibandingkan kebutuhan. ${ }^{24}$ Skor rasio asam lemak keseluruhan subjek 0 karena subjek lebih banyak mengonsumsi lemak jenuh. Hal ini sejalan dengan penelitian di Semarang bahwa asupan lemak jenuh lansia tergolong tinggi. ${ }^{23}$ Penelitian di Meksiko menunjukkan asupan lemak jenuh lansia mencapai $125,6 \%$ dari kebutuhan. ${ }^{39}$

Tidak ada perbedaan status gizi dan kualitas asupan makanan berdasarkan tingkat pendapatan dan aktivitas fisik. Berdasarkan hal tersebut maka tingkat pendapatan dan aktivitas fisik dapat dikendalikan, sehingga tidak mempengaruhi hasil penelitian. Penelitian di Bangladesh menunjukkan bahwa status gizi tidak dipengaruhi oleh tingkat pendapatan. ${ }^{42}$ Tingkat pendapatan menjadi salah satu faktor yang akan menentukan pola makan seseorang. Pendapatan merupakan faktor yang paling menentukan kuantitas dan kualitas makanan. Pendapatan yang rendah akan menyebabkan lemahnya daya beli sehingga tidak dapat memperbaiki kebiasaan makan sesuai yang dianjurkan. Sebaliknya, pendapatan yang lebih tinggi dapat memberikan pengaruh yang positif dalam upaya perbaikan masalah gizi dalam keluarga. ${ }^{43-46}$

Penelitian ini menunjukkan bahwa kualitas asupan makanan terendah terjadi pada subjek yang memiliki frekuensi makan satu kali dalam sehari sehingga skor semua komponen dalam kualitas asupan makanan rendah terutama variasi dan kecukupan. Hal ini sejalan dengan penelitian sebelumnya yang menunjukkan bahwa lansia yang memiliki frekuensi makan lebih sedikit memiliki kualitas asupan makanan yang rendah. ${ }^{20}$ Kualitas asupan makanan lansia sebesar 25-63 poin dan 
hanya 5\% lansia yang memiliki kualitas asupan makanan tergolong baik. Hasil penelitian ini sejalan dengan penelitian di Brazil yang menunjukkan kualitas asupan makanan lansia hanya mencapai skor 22-70 poin. ${ }^{22}$ Penelitian di Korea juga menunjukkan kualitas asupan makanan lansia tergolong rendah dengan rata-rata 51 poin. ${ }^{47}$ Lansia cenderung memiliki asupan makanan yang monoton karena kesulitan untuk menyiapkan makanan maupun terkait kondisi ekonomi. ${ }^{22,48}$

Status gizi lansia yang mengikuti dan tidak mengikuti prolanis menunjukkan perbedaan yang signifikan $(\mathrm{p}=0,029)$ dengan status gizi pada kelompok yang tidak mengikuti prolanis lebih rendah. Lansia yang mengikuti prolanis memiliki status gizi yang tergolong lebih, sedangkan lansia yang tidak mengikuti prolanis memiliki status gizi yang tergolong normal. Hal ini dapat disebabkan semua lansia yang mengikuti prolanis merupakan pasien hipertensi dan/atau diabetes mellitus, sedangkan lansia yang tidak mengikuti prolanis sebagian besar bukan pasien hipertensi dan/atau diabetes mellitus. Sebuah penelitian di Polandia menunjukkan sebanyak 56\% lansia yang mengalami hipertensi memiliki status gizi lebih. ${ }^{49}$ Penelitian di Pekanbaru menunjukkan hasil yang sejalan yaitu sebanyak $75,8 \%$ subjek yang mengalami hipertensi memiliki status gizi overweight dan obesitas. ${ }^{50}$ Berdasarkan laporan Public Health England tahun 2014 menunjukkan bahwa 90\% dewasa yang mengalami diabetes tipe 2 memiliki status gizi overweight dan obesitas. ${ }^{51}$ Hal serupa juga ditunjukkan pada penelitian di Jawa Barat yang menyebutkan $70 \%$ lansia penderita diabetes memiliki status gizi lebih (IMT $>23 \mathrm{~kg} / \mathrm{m}^{2}$ ). ${ }^{40,52}$

Kualitas asupan makanan lansia yang mengikuti prolanis memiliki skor yang lebih tinggi dibandingkan lansia yang tidak mengikuti prolanis, baik dari skor total kualitas asupan makan maupun skor setiap komponennya. Kualitas asupan makanan pada kelompok yang mengikuti prolanis lebih tinggi $(49,0 \pm 7,5)$ dibandingkan kelompok yang tidak mengikuti prolanis $(47,6 \pm 6,1)$. Selain itu, kualitas asupan makanan lansia yang tergolong baik lebih banyak pada kelompok yang mengikuti prolanis. Hal ini sejalan dengan penelitian sebelumnya yang menyatakan lansia yang rutin mengakses layanan kesehatan memiliki kualitas asupan makanan yang lebih baik dan lebih patuh terhadap diet yang direkomendasikan. ${ }^{22,53}$ Hal ini dapat disebabkan lansia yang mengikuti prolanis mendapatkan konseling kesehatan setiap bulannya sehingga mereka lebih banyak mendapatkan pengetahuan terkait kesehatan dan gizi. ${ }^{53}$ Selain itu, lansia yang mengikuti prolanis kondisi kesehatannya terpantau sehingga timbul kesadaran untuk melakukan pembatasan pada beberapa bahan makanan tertentu untuk menjaga kesehatannya dan mengontrol penyakit hipertensi dan/atau diabetes melitus yang dialaminya. Meskipun kualitas asupan makanan lansia yang mengikuti prolanis lebih tinggi namun secara statistik menunjukkan tidak ada perbedaan kualitas asupan makanan yang signifikan antara kelompok yang mengikuti prolanis dan tidak mengikuti prolanis $(p>0,05)$. Hal ini disebabkan rerata skor kedua kelompok hampir sama secara jumlah sehingga tidak jauh beda.

\section{SIMPULAN}

Terdapat perbedaan status gizi antara lansia yang mengikuti dan tidak mengikuti prolanis $(p=0,029)$. Tidak terdapat perbedaan kualitas asupan makanan antara lansia yang mengikuti dan tidak mengikuti prolanis $(\mathrm{p}=0,538)$.

Pemantauan status gizi pada lansia perlu dilakukan secara rutin serta edukasi terkait pentingnya peningkatan kualitas asupan makanan pada lansia harus terus dilakukan sebagai salah satu upaya untuk meningkatkan derajat kesehatan lansia. Penelitian selanjutnya yang terkait uji beda pada prolanis sebaiknya memilih subjek dengan karakteristik yang sama (kedua kelompok merupakan pasien hipertensi dan/atau diabetes mellitus) sehingga hasil penelitian lebih akurat.

\section{DAFTAR PUSTAKA}

1. Presiden Republik Indonesia. Undang-Undang Republik Indonesia No 13 tahun 1998 tentang Kesejahteraan Lanjut Usia. Available from www.bphn.go.id/data/documents/98uu013.pdf

2. Darmojo RB, Martono HH. Buku Ajar BoedhiDarmojo Geriatri (Ilmu Kesehatan Usia Lanjut). 4th ed. Martono HH, Pranarka K, editors. Jakarta: Balai Penerbit FKUI; 2010. 3-115, 634-652 p.

3. Badan Pusat Statistik. Angka Harapan Hidup Penduduk Beberapa Negara (tahun), 1995-2015. Available from https://www.bps.go.id

4. Badan Pusat Statistik. Statistik Penduduk Lanjut Usia 2014. Jakarta; 2015. Available from https://www.bps.go.id/publication/download.html

5. Badan Pusat Statistik. Indeks Pembangunan Manusia (metode baru) Angka Harapan Hidup saat lahir tahun 2010-2016 di Wilayah Jawa Tengah. Available from https://jateng.bps.go.id/

6. Badan Pusat Statistik. Profil Lansia Provinsi Jawa Tengah 2017. Semarang: Java Luhur Makmur Abadi; 2018.

7. Amarya S, Singh K, Sabharwal M. Changes During Aging and Their Association with Malnutrition. J Clin Gerontol Geriatr. 2015;6:7884.

8. Haque MM, Uddin AKMM, Naser MA, Khan MZH, Roy SK, Arafat Y. Health and Nutritional 
Status of Aged People. Chattagram Maa-O Shishu Hosp Med Coll J. 2014;13(3):30-4.

9. Rohmawati N, Asdie AH, Susetyowati. Tingkat Kecemasan, Asupan Makan, dan Status Gizi pada Lansia di Kota Yogyakarta. J Gizi Klin Indones. 2015;12(2):62-71.

10. Xu X, Hall J, Shi Z. Assessing Dietary Quality of Older Chinese People Using the Chinese Diet Balance Index (DBI). PLoS One. 2015;10(3).

11. Pratiwi KA. Gambaran Asupan Energi, Zat Gizi Makro, Status Gizi Lansia, dan Keadaan Fisik Lansia di Posyandu Lansia RW 05 Kelurahan Kuranji Kecamatan Kuranji Kota Padang Tahun 2015 [Skripsi]. Politeknik Kesehatan Kemenkes Padang; 2015.

12. Badan Penyelenggara Jaminan Sosial. Panduan Praktis Prolanis (Program Pengendalian Penyakit Kronis). 2017. p. 1-18. Available from https://bpjs-

kesehatan.go.id/bpjs/dmdocuments/06-

PROLANIS.pdf

13. Manuhutu AAF, Prasetya BEA. Perbedaan Quality of Life Lansia Hipertensi yang Mengikuti dan Tidak Mengikuti Senam Prolanis di Wilayah Benteng Kota Ambon. J Psikol Indones. 2018;7(2):151-60.

14. Badan Pusat Statistik. Profil Kesehatan Kabupaten Wonogiri 2017. Wonogiri: Badan Pusat Statistik Kabupaten Wonogiri; 2018. 14 p.

15. Fatmah. Gizi Usia Lanjut. Jakarta: Penerbit Erlangga; 2010. 8-12, 36-97 p.

16. Guidelines for Data Processing and Analysis of the International Physical Activity Questionnaire (IPAQ) - Short and Long Forms. 2005.

17. Ainsworth BE, Haskell WL, Whitt MC, Irwin ML, Swartz AM. Compendium of Physical Activities: an Update of Activity Codes and MET Intensities. Med Sci Sport Exerc. 2000;32(9):498516.

18. Presiden Republik Indonesia. Undang-Undang Republik Indonesia No 20 tahun 2003 tentang Sistem Pendidikan Nasional. Available from https://kelembagaan.ristekdikti.go.id/wp-

content/uploads/2016/08/UU_no_20_th_2003.pdf

19. Gubernur Jawa Tengah. Upah Minimum pada 35 (Tiga Puluh Lima) Kabupaten/Kota di Provinsi Jawa Tengah tahun 2019. 2018. Available from https://disnakertrans.jatengprov.go.id/umk/daftar

20. Gomes AP, Soares ALG, Goncalves H. Low diet quality in older adults: a population study in southern Brazil. Cienc saude coletiva. 2016;21(11):3417-28.

21. Stoffel LM., Muniz FWMG, Colussi PRG, Rosing CK, Colussi EL. Nutrition Assessment and Associated Factor in the Elderly: a Populationbased Cross-sectional Study. J Nutr. 2018;10410.

22. Fernandes DP de S, Duarte MSL, Pessoa MC, Franceschini S do CC, Ribeiro AQ. Evaluation of
Diet Quality of the Elderly and Associated Factors. J Arch Gerontol Geriatr. 2017;72:17480.

23. Affanti KAN, Candra A. Hubungan Indeks Massa Tubuh dan Asupan Asam Lemak Jenuh dengan Rasio LDL/HDL Serum Lansia. J Nutr Coll. 2015;4(2):189-94.

24. Granic A, Davies K, Adamson A, Kirkwood T, Hill TR, Siervo M, et al. Dietary Patterns and Socioeconomic Status in the Very Old: The Newcastle 85+ Study. PLoS One. 2015;10(10):116.

25. Sundari E, Masdar H, Rosdiana D. Angka Kejadian Obesitas Sentral pada Masyarakat Kota Pekanbaru. J Online Mhs FK. 2015;2(2):1-16.

26. Ng TP, Jin A, Chow KY, Feng L, Nyunt MSZ, Yap KB. Age-dependent Relationships between Body Mass Index and Mortality: Singapore Longitudinal Ageing Study. PLoS One. 2017;12(7):1-11.

27. Lestari MW, Weta IW. Status Gizi Lansia berdasarkan Pengetahuan dan Aktivitas Fisik di Wilayah Kerja Puskesmas Sukawati 1, Gianyar, Bali. JKK. 2017;4(2):56-63.

28. Nur YH, Nuryati $Y$, Resnia R, Santoso AS. Analisis Faktor dan Proyeksi Konsumsi Pangan Nasional: Kasus pada Komoditas: Beras, Kedelai dan Daging Sapi. Litbang Perdagang. 2012;6(1):37-52.

29. Siwi NP, Paskarini I. Hubungan Asupan Karbohidrat, Lemak, dan Protein dengan Status Gizi (Studi Kasus pada Pekerja Wanita Penyadap Getah Karet di Perkebunan Kalijompo Jember). Indones J Public Heal. 2018;13(1):1-12.

30. Arlappa N, Balakrishna N, Kokku SB, Harikumar R, Rao KM, Ravindranath M. Diet and Nutritional Status of the Older Adults in Rural India. J Aging Res Healthc. 2016;1(1):44-57.

31. Meng H, Lin X, Hu L. Evaluation of Nutritional Status and Dietary Intake in Older Adults Living at Home and Nursing Homes in Dongying, China. J Nutr Heal Food Eng. 2016;4(3):451-8.

32. Krok-Schoen JJ, Price AA, Luo M, Kelly OJ, Taylor CA. Low Dietary Intakes and Associated Dietary Patterns and Functional Limitations in An Aging Population: A NHANES Analysis. J Nutr Heal Aging. 2019;23(4):338-47.

33. Khole CV, Soletti A. Nutritional Status of Elderly in the Old Age Homes: A Study in Pune City. Curr Res Nutr Food Sci. 2018;6(1):234-40.

34. Kim D-Y, Kim C-O, Lim H. Quality of Diet and Level of Physical Performance Related to Inflammatory Markers in Community-dwelling Frail, Elderly People. Nutrition. 2017;38:48-53.

35. Kuriyama N, Murakami K, Livingstone MBE, Okubo H, Kobayashi S, Suga H, et al. Development of A Food-based Diet Quality Score for Japanese: Associations of the Score With Nutrient Intakes in Young, Middle-aged and 
Older Japanese Women. J Nutr Sci. 2016;5(41):111.

36. Wilujeng CS, Rochmah W, Susetyowati. Perbedaan Asupan Mikronutrien pada Lansia Penderita Hipertensi Esensial yang Overweight dan Tidak Overweight. J Gizi Klin Indones. 2013;10(1):25-35.

37. Wicaksono T, Noer ER. Perbedaan Asupan Zat Gizi pada Lansia Anemia dan Non Anemia. J Nutr Coll. 2013;2(3):358-63.

38. Aprianti, Magdalena, Yusuf A. Hubungan Asupan Serat, Kolesterol, Natrium dan Olahraga dengan Kadar Kolesterol dan Hipertensi pada Lansia di Kelompok Lansia Wilayah Puskesmas S.Parman Banjarmasin. J Skala Kesehat. 2016;7(1):35-43.

39. Cruz-Gongora V De, Tapia BM, Cuevas-Nasu L, Flores-Aldana M, Shamah-Levy T. Dietary Intake and Adequacy of Energy and Nutrients in Mexican Older Adults: Results from Two National Health and Nutrition Suveys. Salud Publica Mex. 2017;59(3):285-98.

40. Cheung LTF, Chan RSM, Ko GTC, Lau ESH, Chow FCC, Kong APS. Diet Quality is Inversely Associated with Obesity in Chinese Adults with Type 2 Diabetes. Nutr J. 2018;17(63).

41. Abdurrachim R, Hariyawati I, Suryani N. Hubungan Asupan Natrium, Frekuensi dan Durasi Aktivitas Fisik terhadap Tekanan Darah Lansia di Panti Sosial Tresna Werdha Budi Sejahtera dan Bina Laras Budi Luhur Kota Banjarbaru, Kalimantan Selatan. J Indones Nutr Assoc. 2016;39(1):37-48.

42. Debnath SC. Relationship of Socio-economic Status with Nutritional Status Among the Elderly in A Rural Community of Bangladesh. Fam Med Prim Care Rev. 2017;19(2):104-9.

43. Hizni A. Gizi dalam Daur Kehidupan: Gizi Dewasa. In: Hardinsyah, Supariasa IDN, editors. Ilmu Gizi Teori dan Aplikasi. Jakarta: Penerbit Buku Kedokteran EGC; 2016. p. 2019-219.

44. Berg A. Peranan Gizi dalam Pembangunan Nasional. 1st ed. Jakarta: Rajawali; 1986. 61-72 p.

45. Schoufour JD, de Jongue EAL, Jong JCK, van Lenthe FJ, Hofman A, Nunn SPT, et al. Socioeconomic Indicators and Diet Quality in An Older Population. Maturitas. 2018;107:71-7.
46. Hsiao P, Mitchel D, Coffman D, Allman R, Locher J, Sawyer P, et al. Dietary Patterns and Diet Quality Among Diverse Older Adults: The University of Alabama at Birmingham Study of Aging. J Nutr Heal Aging. 2013;17(1):19-25.

47. Kim J, Lee Y, Kyee S, Chung Y-S, Kim J-H, Chon D, et al. Diet Quality and Osteosarcopenic obesity in Community-dwelling Adults 50 years and Older. Maturitas. 2017;104:73-9.

48. Bloom I, Lawrence W, Barker M, Baird J, Dennison E, Sayer AA, et al. What Influences Diet Quality in Older People? A Qualitative Study Among Community-dwelling Older Adults from the Hertfordshire Cohort Study, UK. Public Health Nutr. 2017;20(15):2685-93.

49. Regula J, Smidowicz A, Suliburska J, Bogdanski P. Evaluation of Diet and Nutritional Status in Patients Aged 45+ with Diagnosed, Pharmacologically Treated Arterial Hypertension. Prz Menopauzalny. 2014;18(2):109-14.

50. Try K I, Ernalia Y, Haslinda L. Gambaran Status Gizi Pasien Hipertensi di Puskesmas Melur Pekanbaru. J Online Mhs FK. 2016;3(1):1-12.

51. Mary G, Caroline H, Naomi H, Helen O, Lorraine O. Adult Obesity and Type 2 Diabetes. London: Public Health England; 2014. 5-7 p.

52. Ratnawati D, Siregar T, Wahyudi CT. IbM Kelompok Lansia Penderita Diabetes Melitus di Wilayah Kerja Puskesmas Limo Kota Depok Jawa Barat. J Pengabdi Kpd Masy. 2018;2(2):93104.

53. Puspita FA, Rakhma LR. Hubungan Lama Kepesertaan Prolanis dengan Tingkat Pengetahuan Gizi dan Kepatuhan Diet Pasien Diabetes Mellitus di Puskesmas Gilingan Surakarta. J Dunia Gizi. 2018;1(2):101-11.

54. Kim S, Haines PS, Siega-Riz AM, Popkin BM. The Diet Quality Index-International (DQI-I) Provides an Effective Tool for Cross-National Comparison of Diet Quality as Illustrated by China and the United States. J Nutr. 2003;133(11):3476-84.

55. Gibney MJ, Hartono A. Gizi Kesehatan Masyarakat. 1st ed. Widyastuti P, Hardiyanti EA, editors. Jakarta: Penerbit Buku Kedokteran EGC; 2008. 106 p. 